\title{
Performance of horizontal flow constructed wetland for secondary treatment of domestic wastewater in a remote tribal area of Central India
}

\author{
Reetika Shukla ${ }^{1,2}$, Deepak Gupta ${ }^{1,2}$, Gurudatta Singh ${ }^{1}$ and Virendra Kumar Mishra ${ }^{1,2^{*}}$ (D)
}

\begin{abstract}
The purification of the primary treated domestic sewage was performed in the present study through the horizontal sub-surface flow constructed wetland (CW) of $10 \times 3.5 \mathrm{~m}$ dimension. The study was performed using three setups of CW 1 (Unplanted CW), CW 2 (CW planted with macrophyte Typha latifolia), and CW 3 (CW planted with two species of macrophyte T. latifolia and Commelina benghalensis). The purification experiments were performed by converting one type of CW into the other form sequentially, i.e., CW 1 was built first and after the experiments, it was converted into CW 2 and then CW 3. The CW was filled with a layer of coarse and fine gravel of $70 \mathrm{~cm}$ depth as filter media in 1:2 ratio. Each set of wetland was operated for 3 months (12 wk) during which the treatment performance of wetlands for basic physicochemical parameters was evaluated. The CW was operated in continuous mode at an average hydraulic loading rate of $250 \mathrm{~L} \mathrm{~h}^{-1}$ and the treated effluent was analysed twice every week at four different sampling points having hydraulic retention times (HRT) of 12, 24, 36 and $48 \mathrm{~h}$ for important sewage quality parameters All the three setups of CW were able to clean the primary treated sewage significantly. Among the three sets of wetlands used, CW 3 was the best performer removing 79, 77, 79, 79, and $78 \%$ of biochemical oxygen demand, chemical oxygen demand, nitrate, ammonia, and phosphate respectively in $48 \mathrm{~h} \mathrm{HRT}$. Among the three sets of wetlands, the CW 3 removed the highest percent of total coliforms, fecal coliforms, and E. coli as 64, 61 and 52\% respectively.
\end{abstract}

Keywords: Constructed wetland, Macrophytes, Hydraulic retention times, Domestic wastewater, Typha, Comelina benghalensis

\section{Introduction}

Water resources in India are facing a serious threat of contamination due to the continuous discharge of wastewater from various sources such as domestic wastewater, industrial effluent, and agricultural run-off, etc. [1]. Lack of proper wastewater treatment facilities with consequent disposal of untreated or partially treated wastewater in the aquatic ecosystems leads to the deterioration

\footnotetext{
* Correspondence: virendra78@gmail.com

${ }^{1}$ Institute of Environment and Sustainable Development, Banaras Hindu University, Varanasi 221005, India

2Department of Environmental Science, Indira Gandhi National Tribal University, Amarkantak 484887, India
}

of the water quality in receiving water bodies [2]. According to one estimate, about $70 \%$ of the total water consumed ends in wastewater which is finally disposedoff in lakes, rivers, or freshwater, thus polluting the water resources [3]. Domestic wastewater in India is one of the most important sources contributing to the contamination of water resources [4]. According to the report published by the Indian central agency, Central Pollution Control Board (CPCB) of India, there is a huge difference between the amount of total wastewater generated, i.e., 61,754 MLD $\left(10^{6} \mathrm{~L} \mathrm{~d}^{-1}\right.$ and the amount of total wastewater treated (2, 2963 MLD) in India [4]. 
Thus, the substantial amount of sewage (38,791 MLD) is discharged into a water body in an untreated manner. It is predicted that by 2051 urban and rural India will generate 120,000 and 50,000 MLD of sewage, respectively, with very little probability of complete treatment of all the generated wastewater [5]. Since there are no sewage treatment facilities in rural areas in India and under the existing scenario it will be economically unbearable to develop a sewage treatment facility for all the rural populations in the country. Hence, the generated sewage may be directly discharged in an untreated manner, consequently creating water pollution and at the same time, freshwater availability would be declining [4].

Constructed wetlands (CWs) are man-made, engineered, integrated systems based on principles of the natural wetland; designed for the treatment of various types of wastewaters like grey water, municipal wastewater, industrial wastewater, and agricultural runoff [6-8]. CWs have been adopted as an ecologically sustainable and economically viable solution for the treatment of wastewater [9]. Selection of CWs for wastewater treatment has several advantages, i.e., low-cost setup with longer life, less maintenance requirement, needs no electricity, effective pollutant removal, a self-sustaining system with scenic beauty. The main disadvantage of CWs is its large surface area requirement for its installations, but this can be very useful in rural areas where land availability is not an issue [10].

Horizontal sub-surface flow CW (HSSFCW) is one of the most preferred types of wetland and has been successfully used during the past few decades for the treatment of various types of pollutants from the wastewater [11]. The use of macrophytes in such wetlands makes the system more efficient in comparison to the unplanted wetland [12]. Overall, the performance and efficiency of CWs concerning pollutant removal from the wastewater are governed by its components like growth media, plant, microbes, and pattern of water flow in the wetland system [13]. Coleman et al. [9] reported gravel as an effective filter media for the wastewater treatment and treatment efficiency was better when wetland set up was planted. But later on, research conducted by Priya et al. [14] demonstrated sand as more effective media than gravel in removing pollutants from the wastewater. However, in some studies, the higher removal efficiency was achieved with media having a mixture of both soil and sand [15]. Different types of media such as biochar, zeolite, vermiculite, lime, etc. are also used in CWs for enhancing its performance [16, 17]. CWs can be used in planted or unplanted state and both have been found successful in treating wastewater [9]. In planted CWs different macrophytes such as Cyperus papyrus, Canna, Commelina benghalensis, Eichhornia crassipes, Populus trichocarpa, Phragmites australis, Typha angustifolia,
Hydrilla verticillata, and Salvinia natans were used to treat the municipal wastewater in a vertical flow $\mathrm{CW}$ [18]. In a study conducted by Calheiros et al. [19] five different species of macrophytes, i.e., Canna indica, Typha latifolia, P. australis, Stenotaphrum secundatum, and Iris pseudacorus were used for the treatment of tannery wastewater through $\mathrm{CW}$.

Several studies dealing with the application of CWs for the treatments of municipal wastewater and subsequent reuse of treated effluents have been performed in India [3]. Briefly, Rana and Maiti [20], performed the treatment of municipal wastewater through $\mathrm{CW}$ planted with Colocasia esculenta and T. latifolia, in a mesocosm study with findings able to remove several important parameters like chemical oxygen demand (COD), by $71 \%$; total Kjeldahl nitrogen by $64-72 \%$ and some of the heavy metals. In another study, Bhagwat et al. [21] used Typha aungstifolia and Acorus calamus in CW to treat the landfill leachates. Sudarsan and Srihari [22] setup lab-scale $\mathrm{CW}$ with biochar for the treatment of tannery wastewater and achieved 60 to $70 \%$ removal efficiency for the removal of colour, chromium, biochemical oxygen demand (BOD), and COD.

Considering the advantages of CWs for the treatment of wastewater over the existing technologies, the wetlands can be a preferred technology for the same [4]. However, studies regarding the treatment of wastewater through CWs in the Indian context are still very limited. Most of the studies have been conducted on a lab-scale or at a mesocosm scale; therefore, more studies are required at field scale to establish CW technology as a sustainable approach for wastewater treatment in India [3]. Moreover, the presence of BOD, nutrients, and pathogens in the treated sewage restricts its reuse, which can be restored by the polishing of primary treated wastewater through CW. Due to lack of attention and other priorities, there have been very limited researches on sustainable and natural sewage treatment methods in India. Therefore, the present study was performed to treat the primary treated sewage through CWs to produce treated wastewater which can be reused safely in various sectors.

\section{Materials and methods}

\section{Experimental constructed wetland}

The results of the present study are based on the findings of the operation of the CWs on the campus of Indira Gandhi National Tribal University (IGNTU), Amarkantak, MP, India [3]. The study site is located between $22^{\circ} 80^{\prime} \mathrm{N}$ and $81^{\circ} 75^{\prime} \mathrm{E}$ at an elevation of $1048 \mathrm{~m}$ in the central part of India. The climate of the region is characterized by an average annual rainfall of about $1235 \mathrm{~mm}$ and a normal annual mean maximum and minimum ambient temperature of 31.6 and $18.2^{\circ} \mathrm{C}$, 
respectively. To perform the treatment of primary treated sewage, a HSSFCW with the surface area of 35 $\mathrm{m}^{2}(3.5 \times 10 \mathrm{~m})$ was filled with gravel media (Fig. 1), and a perforated PVC (polyvinylchloride) pipe was inserted vertically upward at a fixed interval for aeration and sample collection. To maintain a gravity flow, a slope of $1^{\circ}$ was maintained from inlet to outlet of the wetland. The present study was conducted with three different settings of CWs. These settings were: (i). CW 1 (unplanted CW/gravel bed) (ii). CW 2 (CW planted with $T$. latifolia giving it $100 \%$ cover to grow) and (iii). CW 3 (CW planted with two different species of macrophyte, T. latifolia and C. benghalensis) in which both the species were given equal cover, i.e., $50 \%$ area of the wetland to grow. Each set of the wetland was operated for the 3 months, after this period the wetland was flushed and converted into next wetland set up by making appropriate changes. To begin with, CW 1 was built (Fig. 1) and filled with gravels of size 26 and $18 \mathrm{~mm}$ in the 1:2 ratio. The depth of gravel column in the CW was maintained up to $70 \mathrm{~cm}$, while the water level within the CW during the operation was always maintained below the column of gravel bed, i.e., a sub-surface flow was always maintained. Perforated PVC interlocked pipes were used to feed the wetland and were inserted horizontally in the wetland from inlet to the rear end of the wetland. A second collection tank of approximately $1 \mathrm{~m}^{3}$ was made to receive and store the treated water. The rear end of the wetland was connected with the collection tank through drainage pipe made up of PVC pipes of $10.2 \mathrm{~cm}$ diameter. Four sampling ports (S1, S2, S3, outlet) were made for the sampling of treated effluent at different hydraulic retention times (HRTs) $(12,24,36$, and $48 \mathrm{~h}$ ).
Initially, just after the establishment, $\mathrm{CW}$ was optimized for various operational parameters such as hydraulic loading rate (HLR), HRT, till the wetland achieved a pseudo steady state. After the initial optimization period of 2 weeks the wetland was ready for further study and provided some promising results from preliminary study [3]. Further, the $\mathrm{CW}$ was investigated for the treatment of primary treated sewage through different settings. To achieve the further treatment, primary treated sewage from the sewage treatment plant (STP) of the IGNTU campus was passed through the experimental CWs in the continuous operation mode. A qualitative change in the different parameters of primary treated sewage at four different HRT, i.e., 12, 24,36 , and $48 \mathrm{~h}$ was observed for three different setups (CW1, CW2 and CW3).

\section{Collection of wetland plants and its adaptability}

Two macrophyte species namely $T$. latifolia and C. benghalensis were grown on $\mathrm{CW}$ to enhance the removal performance of wetland. Emerging plants of both the species were collected from the ponds located nearby village areas and within the university campus. After the collection, plants were washed properly for the removal of soil and debris attached to them, followed by this the macrophytes were planted in the gravel media, in a nursery established at IGNTU campus, after 1 month's adaptation period macrophytes were transferred to the experimental CW. About 14 plants were planted in area of $\mathrm{CW}$ and left for stabilization for about 1 month. During this period the plants were given intermittent irrigation with the pond water. When the macrophytes planted in the CWs were acclimatised to the wetland

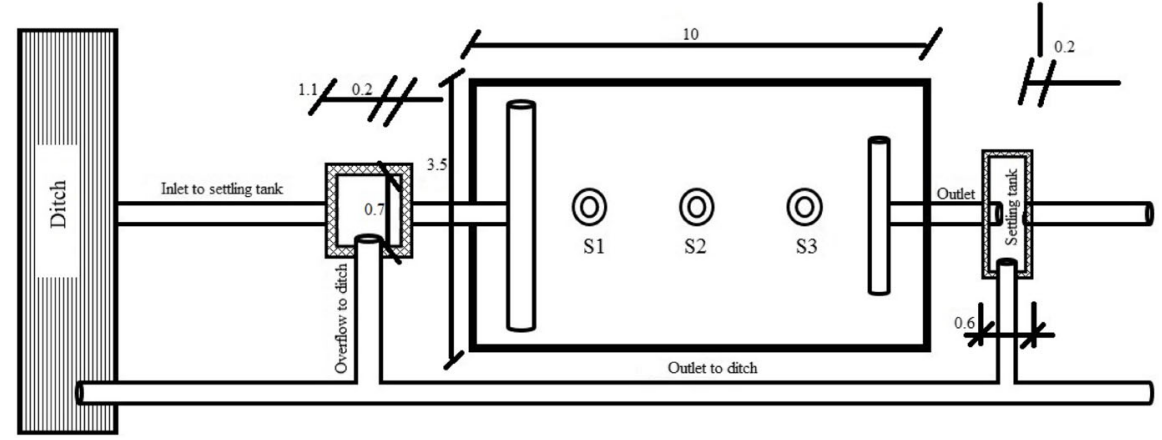

\begin{tabular}{lllll}
\hline S. No. & Sampling points & Distance, $\mathrm{m}$ & HRT, $\mathrm{h}$ & 493 \\
\hline 1 & Inlet port (Inlet of CW) & 0 & 0 & \\
2 & Sampling port 1 (S1) & 2.5 & 12 & 494 \\
3 & Sampling port 2 (S2) & 5.0 & 24 & \\
4 & Sampling port 3 (S3) & 7.5 & 36 & \multirow{2}{*}{495} \\
5 & Outlet port (at the end of CW) & 10 & 48 & \\
\hline
\end{tabular}

Fig. 1 Dimensions and sampling port for the experimental wetland 
environment, experiments with regular monitoring were initiated.

\section{Sampling and analysis of treated and untreated sewage} The primary treated sewage for the experiment was collected from the already existing 200 KLD moving bed biofilm reactor based STP on the IGNTU campus. The primary treated sewage was collected from the settling tank of the existing STP and stored in a $1 \mathrm{~m}^{3}$ collection tank, just before the CW (Fig. 1). From the collection tank, the primary treated sewage was managed to feed the CW at an average HLR of $250 \mathrm{Lh}^{-1}$. The primary treated sewage was analyzed with a frequency of two times a week for various physicochemical parameters listed in Table 1. Samples of primary treated sewage were collected in triplicates and analyzed according to the protocol prescribed in the Standard Methods [23]. All the reagents were prepared in the double-distilled water using AR grade chemicals. The wetland treated sewage samples were also collected twice per week at 12, 24, 36, and $48 \mathrm{~h}$ HRT from sampling points S1, S2, S3 and S4 (Fig. 1) and analyzed as per Standard Methods [23].

The physicochemical analysis of the influent and treated effluent collected from $\mathrm{CW}$ were conducted for temperature, $\mathrm{pH}$, conductivity, acidity, alkalinity, total dissolved solids (TDS), phosphate, nitrate, BOD, and dissolved oxygen (DO). The analyses were conducted on the same day in the research laboratory of the Department of Environmental Science, IGNTU, Amarkantak. The basic parameters viz. temperature, $\mathrm{pH}$, conductivity, and TDS were measured on-site using a calibrated digital pH meter of Hana (model 98,191). A five-day

Table 1 Average physico chemical quality of primary treated sewage used for the study

\begin{tabular}{|c|c|}
\hline $\begin{array}{l}\text { Parameter (in } \mathrm{mg} \mathrm{L}^{-1} \\
\text { unless specified) }\end{array}$ & $\begin{array}{l}\text { Primary treated sewage } \\
\text { Mean } \pm \text { standard deviation } \\
\text { (minimum-maximum) }\end{array}$ \\
\hline $\mathrm{pH}$ [no unit] & $7.8-8.7$ \\
\hline Temp $\left[{ }^{\circ} \mathrm{C}\right]$ & $29.3 \pm 1.1(29.1-30.2)$ \\
\hline Conductivity $\left[\mu \mathrm{S} \mathrm{cm}^{-1}\right]$ & $1133 \pm 35(1083-1193)$ \\
\hline TDS & $566 \pm 17(501-597)$ \\
\hline Chloride & $52 \pm 0.59(51-54)$ \\
\hline BOD & $370 \pm 19(358-387)$ \\
\hline COD & $473 \pm 26(453-498)$ \\
\hline $\mathrm{NO}_{3}-\mathrm{N}$ & $43 \pm 2.1(32-45)$ \\
\hline $\mathrm{PO}_{4}^{---}-\mathrm{P}$ & $13 \pm 0.5(12-15.9)$ \\
\hline $\mathrm{NH}_{4}^{+}$ & $42 \pm 0.1(34-40)$ \\
\hline Total coliform [CFU $100 \mathrm{~mL}^{-1}$ ] & $3 \times 10^{6}$ \\
\hline Fecal coliform [CFU $100 \mathrm{~mL}^{-1}$ ] & $2 \times 10^{5}$ \\
\hline E. coli [CFU $100 \mathrm{~mL}^{-1}$ ] & $3 \times 10^{4}$ \\
\hline
\end{tabular}

BOD was measured using the Winkler's azide modification method, nitrate $\left(\mathrm{NO}_{3}-\mathrm{N}\right)$ was estimated by $\mathrm{UV}$ spectrophotometric method [24] using UV-Visible Spectrophotometers of Thermo Fisher (model evolution 201) and phosphate $\left(\mathrm{PO}_{4}{ }^{3-}\right)$ was measured by using stannous chloride method.

\section{Wetland removal efficiency}

The removal efficiency of different CWs was calculated by the percent difference in values at 0 and $48 \mathrm{~h}$ denoted as the removal percentage ( $\mathrm{r} \%$ ) for all the wetland settings and was calculated by using following equation (Eq. (1))

$$
\operatorname{Removal} \%=\frac{C_{\text {in }}-C_{\text {out }}}{C_{\text {in }}} \times 100
$$

where, $\mathrm{C}_{\text {in }}=$ Concentration of a parameter in influent (at $0 \mathrm{~h}$ ) and $\mathrm{C}_{\text {out }}=$ Concentration of parameter in effluent (at $48 \mathrm{~h}$ ).

\section{Results and discussion}

Physicochemical characteristics of primary treated sewage

The primary treated domestic sewage was collected from the STP of IGNTU campus and that $\mathrm{pH}$, temperature, conductivity, and TDS were analysed immediately after collection (Table 1). The $\mathrm{pH}$ values were ranged from 7.8 to 8.7 . Conductivity values were ranged from 1083 to $1193 \mu \mathrm{S} \mathrm{cm}^{-1}$ in primary treated sewage, this high value indicates presences of highly dissolved inorganic matter. The amount of TDS and total suspended solids (TSS) varied from 501 to $597 \mathrm{mg} \mathrm{L}^{-1}$ and from 448 to $474 \mathrm{mg}$ $\mathrm{L}^{-1}$ in primary treated sewage, respectively. Values of the DO, BOD, and COD were ranged from 1 to 2.1, 358 to 387 , and 453 to $498 \mathrm{mg} \mathrm{L}^{-1}$ respectively in influent wastewater. The concentration of acidity, alkalinity, and hardness was ranged from 123 to 142,93 to $106 \mathrm{mg} \mathrm{L}^{-1}$ $\mathrm{CaCO}_{3}$, and 275 to $299 \mathrm{mg} \mathrm{L}^{-1} \mathrm{CaCO}_{3}$ respectively in primary treated sewage. Nutrients present in the primary treated sewage where $\mathrm{NO}_{3}-\mathrm{N}, \mathrm{NH}_{4}{ }^{+}$, and $\mathrm{PO}_{4}-\mathrm{P}$ varied from 32 to 34,34 to 40 , and 12 to $13.3 \mathrm{mg} \mathrm{L}^{-1}$, respectively.

Primary treated sewage also contained Total Coliform (TC), Fecal Coliform (FC) and E. coli were present in high quantity which was $3 \times 10^{6}, 2 \times 10^{5}$, and $3 \times 10^{4}$ (CFU $\left.100 \mathrm{~mL}^{-1}\right)$, respectively. The values of some important parameters of primary treated sewage collected from IGNTU STP are given in Table 1. Overall, the primary treated sewage was of medium to high strength as the influent to CWs [25].

The removal of pollutants by three different types of CWs (CW 1, CW 2 and CW 3) at different HRT (i.e., 0, 
$12,24,36$, and $48 \mathrm{~h}$ ) has been evaluated for this primary treated sewage. The average physicochemical properties of various pollutants at different stages of treatment in different CWs are given in Table 2.

\section{Performance of the pilot unit to treat primary effluent under different setups}

To perform the further treatment of primary treated sewage, it was allowed to flow into different CWs (CW 1, CW 2 and CW 3) with the HLR of $250 \mathrm{Lh}^{-1}$. Substantial purification of primary treated sewage has resulted through three different types of CWs during different HRTs, and important results are given in coming section (Table 2).

During the experiment, the influent $\mathrm{pH}$ values in different wetland setups were ranged from 7.8 to 8.7; the result obtained from the experiment indicated that the $\mathrm{pH}$ suddenly decreased at $12 \mathrm{~h}$ HRT but there was a gradual increase in CW 1 and CW 3 wetland. In CW 2 $\mathrm{pH}$ value was consistent with increasing HRT. The influent conductivity values were ranged from 1083 to 1193 $\mu \mathrm{S} \mathrm{cm} \mathrm{cm}^{-1}$, it was reduced to 490,422 , and $268 \mu \mathrm{S} \mathrm{cm}^{-1}$ respectively at $48 \mathrm{~h}$ HRT in three different wetlands (CW 1, CW 2 and CW 3). The reduction in conductivity followed the order of $\mathrm{CW} 3>\mathrm{CW} 2>\mathrm{CW} 1$ with $76>$ $63>56 \%$ removal efficiency, respectively (Fig. 2).

TDS values were ranged from 501 to $597 \mathrm{mg} \mathrm{L}^{-1}$ in CW influent it was treated through three different setups of wetland, i.e., CW $1, \mathrm{CW} 2$ and $\mathrm{CW} 3$ and was reduced to 260,269 , and $270 \mathrm{mg} \mathrm{L}^{-1}$, respectively at HRT $48 \mathrm{~h}$. A maximum reduction in TDS was noted by CW 3 with a $54 \%$ removal efficiency (Fig. 2). Similarly, TSS values were ranged from 448 to $474 \mathrm{mg} \mathrm{L}^{-1}$ in influent and after the wetland treatment with three different settings it was reduced to 221,310 , and $322 \mathrm{mg} \mathrm{L}^{-1}$, respectively at HRT $48 \mathrm{~h}$. The maximum removal efficiency for TSS was shown by CW 3 at 53\% (Fig. 2). TSS removal is generally credited to sedimentation and its interaction with microbes for its assimilation, filtration achieved by the media and retention time [26, 27]. The variations in TDS and TSS of wastewater through different setups and at different HRTs are shown in Fig. 3a.

During the present study, the DO values were ranged from 1.0 to $2.1 \mathrm{mg} \mathrm{L}^{-1}$ in influent wastewater, and it was found to be in increasing order in all the CWs with respect to a change in HRT. This could be because of aeration pipes that were installed at a fixed interval, tends to aerate the system, and supply oxygen from the atmosphere which facilitates the oxidation process within the wetland system. In the planted wetland, the effect of the root zone might have enhanced the concentration of DO [28]. BOD values were ranged from 358 to $387 \mathrm{mg} \mathrm{L}^{-1}$ in influent, whereas after $48 \mathrm{~h}$ HRT the BOD was reduced to $77 \mathrm{mg} \mathrm{L}^{-1}$ in CW 3, $147 \mathrm{mg} \mathrm{L}^{-1}$ in CW 2, and $153 \mathrm{mg} \mathrm{L}^{-1}$ in CW 1, with maximum BOD removal of 79\% (Fig. 2) done by CW 3. Similarly, the COD values were ranged from 453 to $498 \mathrm{mg} \mathrm{L}^{-1}$ in influent wastewater, after $48 \mathrm{~h} \mathrm{HRT}$ it was reduced to $223 \mathrm{mg} \mathrm{L}^{-1}$ in CW 1, $202 \mathrm{mg} \mathrm{L}^{-1}$ in CW 2, and $109 \mathrm{mg} \mathrm{L}^{-1}$ in CW 3, maximum COD removal with $78 \%$ was achieved in $\mathrm{CW}$ 3.

Removal of BOD and COD through CW was poor at lower HRTs, i.e., 12 or $24 \mathrm{~h}$ but it steadily increased with increasing HRT [29] (Fig. 3b). Nitrate values were ranged from 32 to $45 \mathrm{mg} \mathrm{N} \mathrm{L}^{-1}$ in influent; after $48 \mathrm{~h}$ HRT it was reduced to 17,16 and $7 \mathrm{mg} \mathrm{N} \mathrm{L}^{-1}$ in $\mathrm{CW} 1$, $\mathrm{CW} 2$ and CW 3, respectively, with the maximum removal of $79 \%$ in CW 3 (Fig. 3c) which made the treated effluent almost comparable to secondary treated wastewater [3].

Table 2 Removal of physicochemical and biological parameters of primary treated sewage through constructed wetlands (CW 1, CW 2 and (W 3)

\begin{tabular}{|c|c|c|c|c|c|c|c|c|c|}
\hline \multirow{2}{*}{$\begin{array}{l}\text { Parameters (in } \mathrm{mg} \mathrm{L}^{-1} \\
\text { unless specified) }\end{array}$} & \multicolumn{3}{|l|}{ CW 1} & \multicolumn{3}{|l|}{ CW 2} & \multicolumn{3}{|l|}{ CW 3} \\
\hline & $\begin{array}{l}\mathrm{Oh} \\
\text { (influent) }\end{array}$ & $\begin{array}{l}48 \mathrm{~h} \\
\text { (effluent) }\end{array}$ & $\begin{array}{l}\text { Removal } \\
\text { (\%) }\end{array}$ & $\begin{array}{l}\mathrm{Oh} \\
\text { Influent) }\end{array}$ & $\begin{array}{l}48 \mathrm{~h} \\
\text { (effluent) }\end{array}$ & $\begin{array}{l}\text { Removal } \\
(\%)\end{array}$ & $\mathrm{O} \mathrm{h}$ (influent) & $\begin{array}{l}48 \mathrm{~h} \\
\text { (effluent) }\end{array}$ & $\begin{array}{l}\text { Removal } \\
(\%)\end{array}$ \\
\hline TDS & 547 & 270 & 50 & 566 & 268 & 52 & 565 & 260 & 54 \\
\hline TSS & 458 & 321 & 30 & 460 & 309 & 32 & 467 & 220 & 53 \\
\hline BOD & 376 & 152 & 59 & 375 & 147 & 61 & 368 & 76 & 79 \\
\hline COD & 473 & 223 & 53 & 483 & 202 & 58 & 486 & 109 & 77 \\
\hline NO3--N & 35.2 & 16.8 & 52.3 & 43.4 & 15.6 & 64. & 33.0 & 6 & 79.3 \\
\hline $\mathrm{NH}_{4}^{+}$ & 36.5 & 17.7 & 51.5 & 38.6 & 15.3 & 60.3 & 36.5 & 7.5 & 79.4 \\
\hline $\mathrm{PO}_{4}^{---}$ & 15.8 & 5.6 & 64 & 12 & 4 & 61 & 13 & 2.9 & 78 \\
\hline Total coliform (CFU $100 \mathrm{~mL}^{-1}$ ) & $3 \times 10^{6}$ & $1.8 \times 10^{6}$ & 39 & $2.9 \times 10^{6}$ & $1.7 \times 10^{6}$ & 41 & $3.1 \times 10^{6}$ & $1.1 \times 10^{6}$ & 64 \\
\hline Fecal coliform (CFU $100 \mathrm{~mL}^{-1}$ ) & $2 \times 10^{5}$ & $1.4 \times 10^{5}$ & 30 & $1.8 \times 10^{5}$ & $0.9 \times 10^{5}$ & 50 & $1.6 \times 10^{5}$ & $0.6 \times 10^{5}$ & 61 \\
\hline E. coli (CFU $100 \mathrm{~mL}^{-1}$ ) & $3 \times 10^{4}$ & $1.95 \times 10^{4}$ & 35 & $2.9 \times 10^{4}$ & $1.6 \times 10^{4}$ & 45 & $3.1 \times 10^{4}$ & $1.5 \times 10^{4}$ & 52 \\
\hline
\end{tabular}

No. of samples $(\mathrm{N})=24$ 


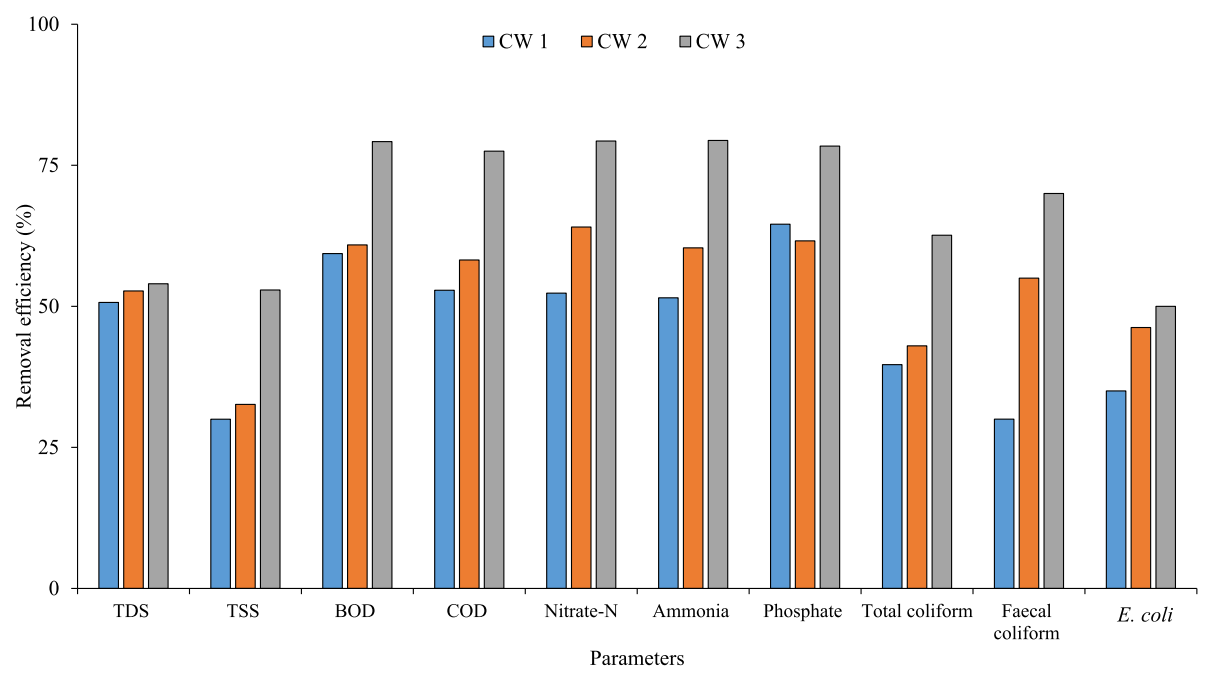

Fig. 2 Removal efficiency of various parameters of primary treated sewage through different setups of constructed wetland

\section{】 $\mathrm{TDS} \square \mathrm{TSS} \square \mathrm{BOD} \square \mathrm{COD} \square$ Nitrate-N $\square$ Ammonia $\square$ Phosphate}

(a)

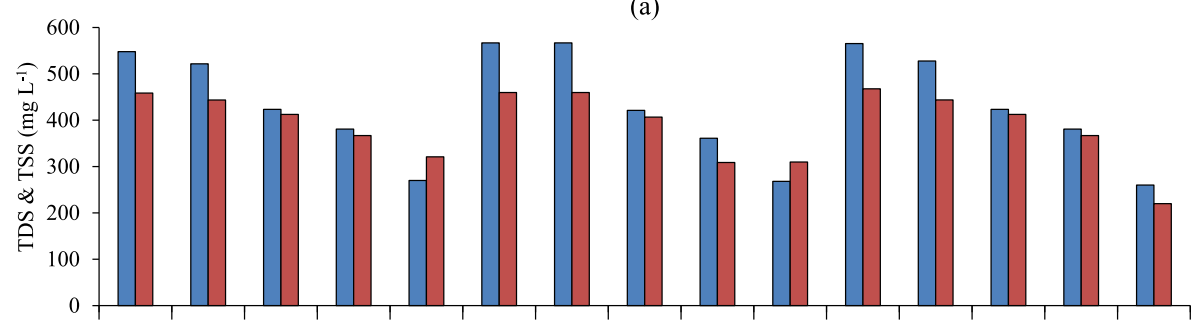

(b)

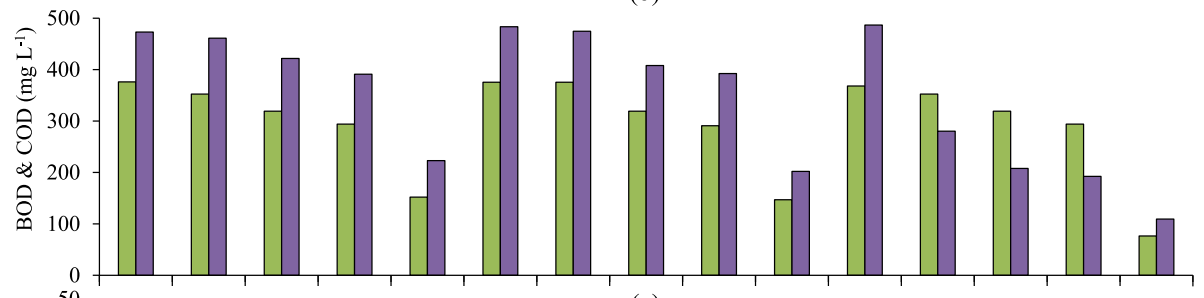

(c)

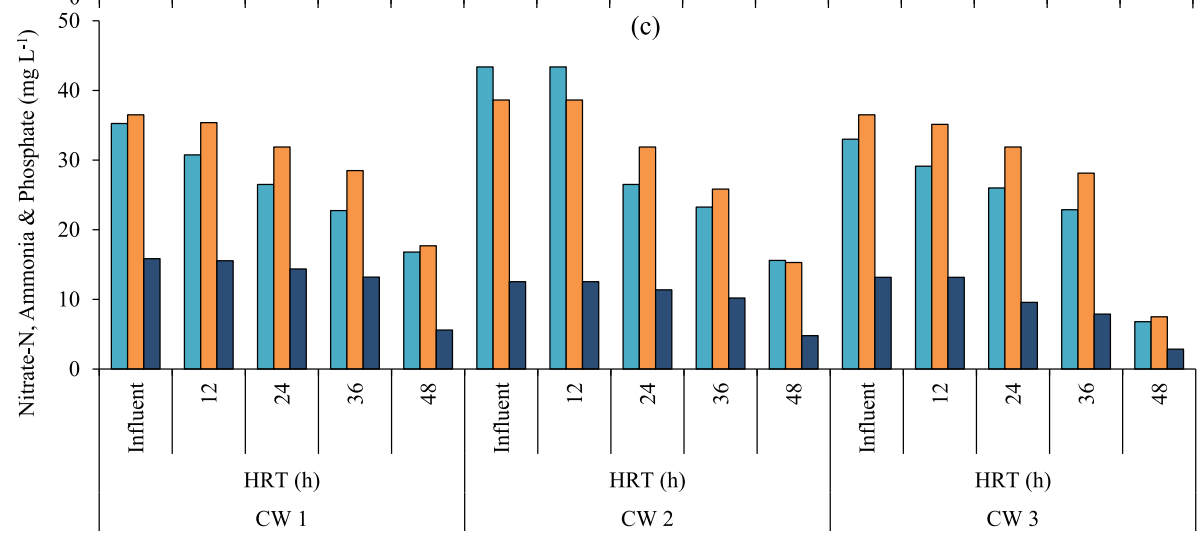

Fig. 3 Variation in physicochemical properties (TDS, TSS, BOD, COD, Nitrate-N, Ammonia, \& Phosphate) of primary treated sewage through different set of constructed wetlands as a function of HRT 
Microbial activity plays a vibrant role in CW to remove the nitrate through denitrification processes indulging in plant uptake and microbial catabolic action [30]. Ammonia, the other important parameter was ranged from 34 to $40 \mathrm{mg} \mathrm{L}^{-1}$ in influent and after $48 \mathrm{~h}$ HRT it was reduced to $18 \mathrm{mg} \mathrm{L}^{-1}$ in CW $1,15 \mathrm{mg} \mathrm{L}^{-1}$ in CW 2, and $8 \mathrm{mg} \mathrm{L}^{-1}$ in CW 3, with a maximum of $80 \%$ by CW 3 (Fig. 3c). Phosphate values were ranged from 12 to 16 $\mathrm{mg} \mathrm{L}^{-1}$ in influent and after $48 \mathrm{~h}$ HRT it was reduced to $5.6 \mathrm{mg} \mathrm{L}^{-1}$ in CW $1,4.8 \mathrm{mg} \mathrm{L}^{-1}$ in CW 2, and $2.9 \mathrm{mg}$ $\mathrm{L}^{-1}$ in CW 3, with maximum phosphate removal of $78 \%$ by CW 3 (Fig. 3). Paruch et al. [31] have reported phosphate removal from domestic wastewater up to $90 \%$ in HSSFCW. The gravel bed used in CW alone has the potential to remove about $20-30 \%$ phosphate concentration from wastewater [32]. The variations in the concentration of nitrate, ammonia, and phosphate of wastewater at different HRTs in different setups are shown in Fig. 3c.

\section{Microbial treatment}

The present study has demonstrated a substantial removal of TC, FC, and E. coli from primary treated sewage during $48 \mathrm{~h} \mathrm{HRT}$. Most probable number (MPN) of $\mathrm{TC}$ was reduced from $3 \times 10^{6}\left(\mathrm{CFU}^{-1} 100 \mathrm{~mL}^{-1}\right)$, to $1.8 \times 10^{6}\left(\mathrm{CFU}^{-1} 100 \mathrm{~mL}^{-1}\right)$ in $\mathrm{CW} 1$, from $2.9 \times 10^{6}$ to $1.7 \times 10^{6}\left(\mathrm{CFU}^{-1} 100 \mathrm{~mL}^{-1}\right)$ in CW 2 and from $3.1 \times 10^{6}$ to $1.1 \times 10^{6}\left(\mathrm{CFU}^{-1} 100 \mathrm{~mL}^{-1}\right)$ in $\mathrm{CW} 3$ as shown in Fig. 4; the removal efficiency of TC was achieved maximum by CW 3 (64\% followed by CW 2 (41\%) and then CW 1 (39\%). FC initial concentration was found to be $2 \times 10^{5}, 1.8 \times 10^{5}, 1.55 \times 10^{5}\left(\mathrm{CFU} / 100 \mathrm{~mL}^{-1}\right)$ for influent (primary treated sewage at $0 \mathrm{~h}$ ) entering in $\mathrm{CW} 1, \mathrm{CW} 2$ and CW 3 and when passed through CWs, it was reduced to $1.4 \times 10^{5} ; 0.9 \times 10^{5}$; and $0.6 \times 10^{5}\left(\mathrm{CFU}^{-1} 100\right.$ $\mathrm{mL}^{-1}$ ) respectively. Removal efficiency of different setups for FC removal were in the order of $\mathrm{CW} 3$ $(61 \%)>$ CW $2(50 \%)>$ CW 1 (30\%).

MPN of E. coli in influent was estimated to be $3 \times 10^{4}$, $2.9 \times 10^{4}$, and $3.1 \times 10^{4}\left(\mathrm{CFU} 100 \mathrm{~mL}^{-1}\right)$ for $\mathrm{CW} 1, \mathrm{CW}$ $2, \mathrm{CW} 3$ respectively and when it was passed through these three CWs its MPN was decreased to $2.0 \times 10^{4}$; $1.6 \times 10^{4}$ and $1.6 \times 10^{4}\left(\mathrm{CFU} 100 \mathrm{~mL}^{-1}\right)$ respectively. Overall, the removal efficiency of $E$. coli was in the order of CW 3 (52\%) > CW 2 (45\%) > CW 1 (35\%).

In CW 1 (unplanted system) microbial removal might be due to the natural die-off, sedimentation [33], mechanical filtration [34, 35], and bio-film treatment [36]; HRT also plays a role in the microbial reduction in the system [37]. In CW 2 and CW 3 (planted system) microbes were more efficiently removed than $\mathrm{CW} 1$ (unplanted system). This might be achieved by the above processes and in addition to it, several processes such as oxidation, i.e., the release of oxygen from the rhizospheric zone of macrophytes in CW can be key driving factors [10]. Biocides, i.e., roots excretion by macrophytes and bactericidal excretion have the potential to destroy TC, FC, and pathogens $[10,37,38]$ and variety of macrophytes [39] have played an important role in this. Overall, the result obtained from the experiments indicated that $\mathrm{CW} 3$, i.e., wetland planted with $T$. latifolia and $C$. benghalensis has good removal efficiency to combat microbial population such as TC, FC and E. coli present in primary treated wastewater (Figs. 2 and 4).

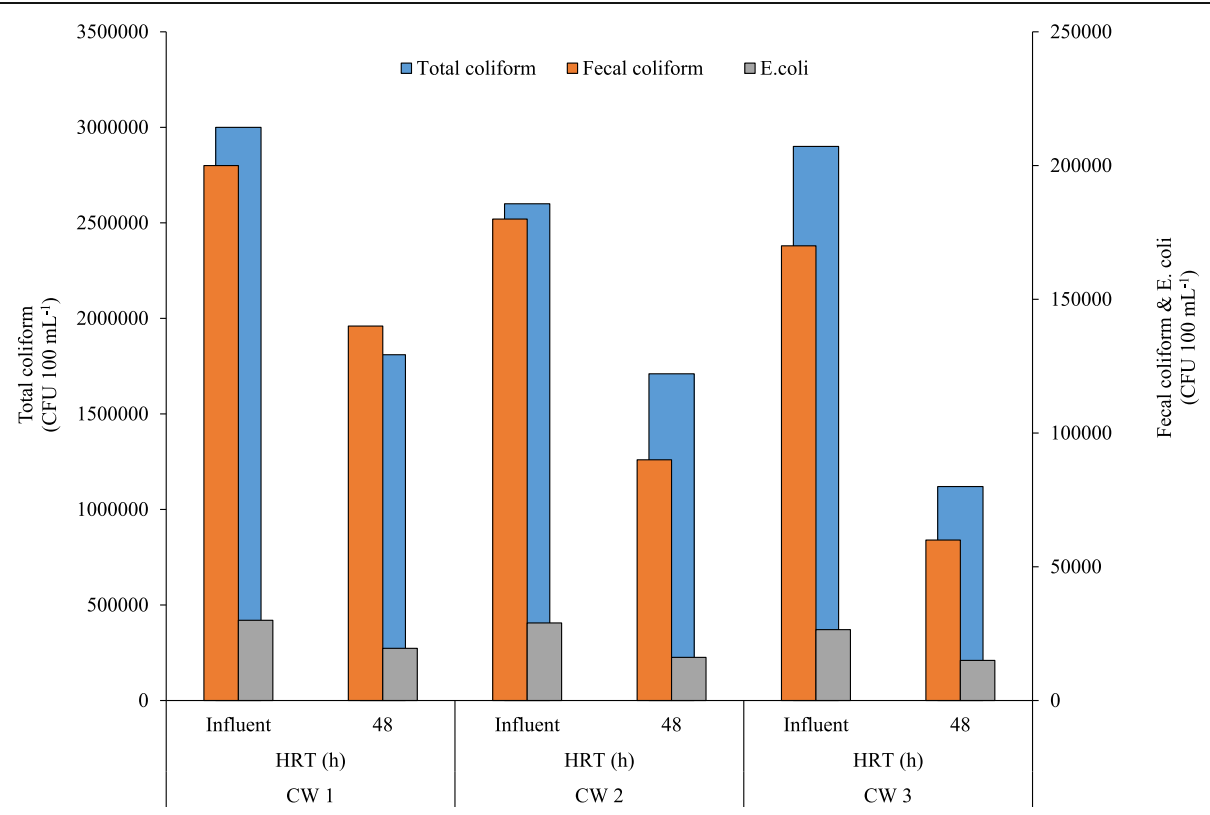

Fig. 4 Variation in coliform (Total, Fecal and E. coli) of primary treated sewage through the constructed wetland 


\section{General mechanisms involved in the wetland for the treatment of various contaminants}

The results of experiments under the present investigation have shown a satisfactory treatment of various parameters by the CWs. The quality of the wetland treated effluent by CW 3 has fulfilled the established norms of secondary treated wastewater set by the CPCB [3]. The removal of these parameters was in line with some of the important studies conducted in other parts of the world $[10,17]$. Treatment of various parameters of primary treated sewage such as BOD, COD, nitrogen, phosphate, and pathogens in a CW was facilitated by a combination of various natural processes including physical, chemical, and biological processes. Most of the organic matter contained in the wetland are stabilized by diverse microbial consortia [40-42]. The degree of treatment by CW depends upon the length of HRT, type of filter media, plant species used, and nature of microbial consortia. Longer retention time speeds up the treatment of contaminants, although, too-long retention times can have detrimental effects [43, 44]. Low water velocity coupled with gravel or sand media in HSSFCW promotes settling and adsorption of solid materials [45].

The principal physical mechanisms for the removal of TSS are sedimentation and interception. It is noteworthy that TSS production may occur in the wetland due to the death of microbes, fragmentation, detritus from plants, and formation of chemical precipitates [46]. Formation of biofilm over the filter media also supports the removal of TSS, as this biofilm adsorbs colloidal and soluble compounds where they may be metabolized and converted into soluble compounds [46, 47]. The HSSF CWs are highly efficient in removing organic loads such as BOD, COD, nitrogen (nitrate, ammonia), phosphate, and pathogens from the wastewater [48]. Organic contaminants in settleable forms are treated by deposition, filtration, microbial degradation (aerobic \& anaerobic), and plant uptake. Microbial degradation is the predominant process in removing the BOD which is removed.

\section{Mechanism for nitrogen removal}

CWs have been proven successful in removing the nitrogen in an economical and ecologically sustainable way from municipal wastewater and industrial wastewater $[46,48]$. Our results to remove nitrogen from primary treated sewage agreed with many of the studies [48]. The removal process of nitrogen from $\mathrm{CW}$ is regulated by various steps, i.e., volatilization, ammonification, nitrification/denitrification, and plant uptake [46, 48]. More than half of the nitrogen content of municipal wastewater is found to be in the form of ammonia and organic nitrogen. In wetlands, the main removal mechanism for nitrogen is essentially a microbial process, which consists of nitrification followed by denitrification. In wetlands, the nitrogen cycle is coupled with the carbon cycle, mainly through the denitrification process [42]. Organic nitrogen is converted to ammonia in the wetland by the process of decomposition and mineralization. Biological nitrification followed by denitrification is a major pathway for nitrogen removal in wetlands [42].

\section{Mechanism for removal of phosphate}

Phosphate is required for biological growth, but an excess of phosphate leads to eutrophication and other water quality problems in the ecosystem. Phosphate removal mechanisms in wetland include adsorption, filtration, precipitation, assimilation, and sedimentation [10, $36,47]$. The configuration of CW provides broad uptake of phosphate by biofilm, plant growth as well as by sedimentation and filtration of suspended materials. It is stored in the sediments, biota, and the water. The process of phosphate removal in CW depends upon redox chemistry, $\mathrm{pH}$, and temperature of the wetland. At low oxygen concentration phosphate is liberated from the sediments and if the anaerobic condition is not reversed it leaves the wetland. Due to the limited contact opportunity between the wetland and phosphate, its removal in most of the CWs is not very efficient, however, our study removed almost $60 \%$ of phosphate by CW 3 which can be treated as an efficient performance. The use of sand increases the phosphate retention capacity for large systems due to the reduced hydraulic conductivity of sand compared to gravel $[17,24]$.

\section{Conclusions}

Horizontal sub-surface flow constructed wetland under present investigation treated strong strength primary treated sewage after HRT of $48 \mathrm{~h}$. Three different setups of CWs (CW 1; CW 2; and CW 3) have achieved good removal efficiency for the removal of various physicochemical and biological parameters. Using gravel as a substrate, at different HRTs $(12,24,36$, and 48 h) it was effective in reducing almost all the physicochemical as well as some microbial parameters. The performance of planted CW was found better in comparison to the unplanted wetland and the removal of various parameters increased with increasing HRT (up to $48 \mathrm{~h}$ ). The easy and economical operation of CW suggested that the HSSFCW can act as a better alternative in comparison to conventional wastewater treatment plants. During approximately 1 year of operation, the performance of the different CWs has continuously enhanced for the treatment of primary treated sewage. The quality of wetland treated effluent was within the permissible limits prescribed by a regulatory authority such as the CPCB of India [44]. This methodology can be an ideal solution to achieve the goal of complete sewage treatment in India. 
Various factors such as easy availability of land, availability of wetland filter media (gravel and sand) in the local area, and availability large number of native macrophytes in the study area makes this technology an ideal option for the sewage treatment in such areas of India.

\section{Acknowledgments}

The authors are thankful to The Vice-Chancellor, Indira Gandhi National Tribal University, Amarkantak, M.P. (India) for financial assistance for wetland construction and providing land for the wetland.

\section{Authors' contributions}

The corresponding author VKM has conceptualized and designed the study, also supervised in manuscript writing, data interpretation the first author RS have performed fieldwork and lab work as well as for manuscript writing. The authors DG and GS have helped in lab work manuscript writing and analysis of data. The author(s) read and approved the final manuscript.

\section{Funding}

The author Reetika is thankful to the University Grant Commission (UGC), for providing financial assistance in the form of Research Fellowship. This work was partly supported by the Indira Gandhi National Tribal University, Amarkantak, MP through the In-House Research Grant in form of Young Scientist Grant to Dr. Virendra Kumar Mishra.

\section{Availability of data and materials}

The datasets used and/or analysed during the current study are available from the corresponding author on reasonable request. All data generated or analysed during this study are included in this published article [and its supplementary information files]

\section{Declarations}

\section{Competing interests}

The authors declare that they have no competing interests.

\section{Received: 26 February 2020 Accepted: 3 March 2021}

Published online: 19 March 2021

\section{References}

1. Veldkamp TIE, Wada Y, Aerts JCJH, Ward PJ. Towards a global water scarcity risk assessment framework: incorporation of probability distributions and hydro-climatic variability. Environ Res Lett. 2016;11:024006.

2. Wilhite DA, Sivakumar MVK, Pulwarty R. Managing drought risk in a changing climate: the role of national drought policy. Weather Clim Extremes. 2014;3:4-13.

3. Mishra VK, Otter P, Shukla R, Goldmaier A, Alvarez JA, Khalil N, et al. Application of horizontal flow constructed wetland and solar driven disinfection technologies for wastewater treatment in India. Water Pract Technol. 2018;13:469-80.

4. CPCB. Inventorization of Sewage Treatment Plants. Delhi: Central Pollution Control Board; 2015

5. Kamyotra JS, Bhardwaj RM. Municipal wastewater management in India. In: India infrastructure report 2011. Water: policy and performance for sustainable development. New Delhi: Oxford University Press; 2011. p. 299-311.

6. Poach ME, Hunt PG, Vanotti MB, Stone KC, Matheny TA, Johnson MH, et al Improved nitrogen treatment by constructed wetlands receiving partially nitrified liquid swine manure. Ecol Eng. 2003;20:183-97.

7. Mello D, Carvalho KQ, Passig FH, Freire FB, Borges AC, Lima MX, et al. Nutrient and organic matter removal from low strength sewage treated with constructed wetlands. Environ Technol. 2019:40:11-8.

8. Laber J, Haberl R, Shrestha R. Two-stage constructed wetland for treating hospital wastewater in Nepal. Water Sci Technol. 1999;40:317-24.

9. Coleman J, Hench K, Garbutt K, Sexstone A, Bissonnette G, Skousen J. Treatment of domestic wastewater by three plant species in constructed wetlands. Water Air Soil Poll. 2001:128:283-95.

10. Kadlec RH, Wallace S. Treatment wetlands. 2nd Boca Raton: CRC Press; 2009.
11. Taylor CR, Hook PB, Stein OR, Zabinksi CA. Seasonal effects of 19 plant species on COD removal in subsurface treatment wetland microcosms. Ecol Eng. 2011;37:703-10

12. Zhu $\mathrm{DL}$, Sun $\mathrm{C}$, Zhang $\mathrm{HH}$, Wu ZL, Jia B, Zhang $Y$. Roles of vegetation, flow type and filled depth on livestock wastewater treatment through multi-level mineralized refuse-based constructed wetlands. Ecol Eng. 2012;39:7-15.

13. Rai UN, Tripathi RD, Singh NK, Upadhyay AK, Dwivedi S, Shukla MK, et al. Constructed wetland as an ecotechnological tool for pollution treatment for conservation of Ganga river. Bioresour Technol. 2013;148:535-41.

14. Priya, Sharma G, Brighu U. Comparison of different types of media for nutrient removal efficiency in vertical upflow constructed wetlands. Int J Env Eng Man. 2013:4:405-16.

15. Sirianuntapiboon S, Kongchum M, Jitmaikasem W. Effects of hydraulic retention time and media of constructed wetland for treatment of domestic wastewater. Afr J Agr Res. 2006:1:27-37.

16. Zhu LD, Li ZH, Ketola T. Biomass accumulations and nutrient uptake of plants cultivated on artificial floating beds in China's rural area. Ecol Eng. 2011;37:1460-6.

17. Brix H, Arias CA, del Bubba M. Media selection for sustainable phosphorus removal in subsurface flow constructed wetlands. Water Sci Technol. 2001; 44:47-54.

18. Kumar M, Singh R. Assessment of pollutant removal processes and kinetic modelling in vertical flow constructed wetlands at elevated pollutant loading. Environ Sci Pollut R. 2019;26:18421-33.

19. Calheiros CSC, Rangel AOSS, Castro PML. Constructed wetland systems vegetated with different plants applied to the treatment of tannery wastewater. Water Res. 2007;41:1790-8.

20. Rana V, Maiti SK. Municipal wastewater treatment potential and metal accumulation strategies of Colocasia esculenta (L.) Schott and Typha latifolia L. in a constructed wetland. Environ Monit Assess. 2018:190:328.

21. Bhagwat RV, Boralkar DB, Chavhan RD. Remediation capabilities of pilotscale wetlands planted with Typha aungstifolia and Acorus calamus to treat landfill leachate. J Ecol Environ. 2018;42:23.

22. Sudarsan JS, Srihari V. Evaluation of adsorption capacity of biochar mixed substrate to treat tannery wastewater by constructed wetland. AIP Conf Proc. 2019;2112:020176.

23. APHA. Standard methods for the examination of water and wastewater. 22nd. Washington, DC: American Public Health Association; 2012

24. Sotirakou E, Kladitis G, Diamantis N, Grigoropoulou H. Ammonia and phosphorus removal in municipal wastewater treatment plant with extended aeration. Global Nest J. 1999:1:47-53.

25. Burton FL, Stensel HD, Techobanoglous G. Wastewater engineering: treatment and resource recovery. 5th New York: McGraw-Hill Higher Education; 2014

26. Manios T, Stentiford El, Millner P. Removal of total suspended solids from wastewater in constructed horizontal flow subsurface wetlands. J Environ Sci Heal A. 2003:38:1073-85.

27. Wu SB, Austin D, Liu L, Dong RJ. Performance of integrated household constructed wetland for domestic wastewater treatment in rural areas. Ecol Eng. 2011;37:948-54

28. Brix $\mathrm{H}$, Schierup $\mathrm{HH}$. Soil oxygenation in constructed reed beds: the role of macrophyte and soil-atmosphere interface oxygen transport. In: Cooper PF, Findlater BC, editors. Constructed wetlands in water pollution control. Oxford: Pergamon Press; 1990. p. 53-66.

29. Reed SC, Brown D. Subsurface flow wetlands - a performance evaluation. Water Environ Res. 1995;67:244-8.

30. Vymazal J. The use constructed wetlands with horizontal sub-surface flow for various types of wastewater. Ecol Eng. 2009;35:1-17.

31. Paruch AM, Mæhlum T, Haarstad K, Blankenberg AGB, Hensel G. Performance of constructed wetlands treating domestic wastewater in Norway over a quarter of a century - options for nutrient removal and recycling. In: Vymazal J, editor. Natural and constructed wetlands. Cham: Springer; 2016. p. 41-55.

32. Prochaska CA, Zouboulis Al. Removal of phosphates by pilot vertical-flow constructed wetlands using a mixture of sand and dolomite as substrate. Ecol Eng. 2006:26:293-303.

33. Green MB, Griffin P, Seabridge JK, Dhobie D. Removal of bacteria in subsurface flow wetlands. Water Sci Technol. 1997:35:109-16.

34. Stevik TK, Aa K, Ausland G, Hanssen JF. Retention and removal of pathogenic bacteria in wastewater percolating through porous media: a review. Water Res. 2004;38:1355-67. 
35. Kaseva ME. Performance of a sub-surface flow constructed wetland in polishing pre-treated wastewater - a tropical case study. Water Res 2004;38: 681-7.

36. Vacca G, Wand H, Nikolausz M, Kuschk P, Kastner M. Effect of plants and filter materials on bacteria removal in pilot-scale constructed wetlands. Water Res. 2005;39:1361-73.

37. Vymazal J. Removal of enteric bacteria in constructed treatment wetlands with emergent macrophytes: a review. J Environ Sci Heal A. 2005:40:1355-67.

38. Soto F, Garcia M, de Luis E, Becares E. Role of Scirpus lacustris in bacterial and nutrient removal from wastewater. Water Sci Technol. 1999:40:241-7.

39. Brix H. Do macrophytes play a role in constructed treatment wetlands? Water Sci Technol. 1997:35:11-7.

40. Hench KR, Bissonnette GK, Sexstone AJ, Coleman JG, Garbutt K, Skousen JG. Fate of physical, chemical, and microbial contaminants in domestic wastewater following treatment by small constructed wetlands. Water Res. 2003;37:921-7

41. Dong Y, Scholz M, Harrington R. Statistical modeling of contaminants removal in mature integrated constructed wetland sediments. J Environ Eng. 2012;138:1009-17.

42. Li M, Liang ZL, Callier MD, d'Orbcastel ER, Ma XN, Sun LL, et al. Nitrogen and organic matter removal and enzyme activities in constructed wetlands operated under different hydraulic operating regimes. Aquaculture. 2018; 496:247-54.

43. Brix $\mathrm{H}$, Arias $\mathrm{CA}$. The use of vertical flow constructed wetlands for on-site treatment of domestic wastewater: new Danish quidelines. Ecol Eng. 2005; 25:491-500.

44. Vymazal J. Removal of nutrients in various types of constructed wetlands. Sci Total Environ. 2007;380:48-65.

45. USEPA. Manual - constructed wetlands treatment of municipal wastewaters. Washington, DC: US Environmental Protection Agency; 2000.

46. Vymazal J, Brix H, Cooper PF, Herberl R, Perfler R, Laber J. Removal mechanisms and types of constructed wetlands. In: Vymazal J, Brix $\mathrm{H}$, Cooper PF, Green MB, Herberl R, editors. Constructed wetlands for wastewater treatment in Europe. Leiden: Backhuys Publishers; 1998. p. $17-66$.

47. Gopal B, Goel U. Competition and allelopathy in aquatic plant communities. Bot Rev. 1993;59:155-210.

48. Williams J, Bahgat M, May E, Ford M, Butler J. Mineralisation and pathogen removal in gravel bed hydroponic constructed wetlands for wastewater treatment. Water Sci Technol. 1995;32:49-58.

\section{Publisher's Note}

Springer Nature remains neutral with regard to jurisdictional claims in published maps and institutional affiliations.

Ready to submit your research? Choose BMC and benefit from:

- fast, convenient online submission

- thorough peer review by experienced researchers in your field

- rapid publication on acceptance

- support for research data, including large and complex data types

- gold Open Access which fosters wider collaboration and increased citations

- maximum visibility for your research: over $100 \mathrm{M}$ website views per year

At $\mathrm{BMC}$, research is always in progress.

Learn more biomedcentral.com/submissions 